\title{
New Diagnostic Strategies in Infection Safety: The (R)evolution?
}

\author{
Jens Dreier ${ }^{a}$ Holger Hennig ${ }^{b}$ \\ a Institute for Laboratory and Transfusion Medicine, Heart and Diabetes Center North Rhine Westphalia, University Hospital, \\ Ruhr University Bochum, Bad Oeynhausen, Germany; \\ bInstitute of Transfusion Medicine, University Hospital of Schleswig-Holstein, Lübeck, Germany
}

Infection safety of blood components is still a major topic in transfusion medicine. In the last decades the worldwide routine implementation of nucleic acid amplification techniques (NAT) has led to the prevention of several transfusion-transmitted infections. The main emphasis was placed on the Big Three: hepatitis $\mathrm{C}$ virus (HCV), human immunodeficiency virus (HIV), and hepatitis $B$ virus (HBV). In addition, further targets were tested (e.g. hepatitis A virus (HAV), parvovirus B19 (B19V)) due to the requirements of the plasma fractionation industry or, in the case of WestNile virus (WNV) or hepatitis E virus (HEV), due to new risk assessments. In 1997, the German blood centers were global forerunners in the introduction of viral NAT screening [1]. Despite the cost and logistical challenges to blood banks, NAT testing was implemented in a voluntary, later mandated manner. The molecular genetic techniques evolved from manually to fully automated performed steps, including sample pooling, nucleic acid extraction, amplification of specific targets, and detection. Today, terms like hands-on time, walk-away time, time to result, and high throughput are in the front line when thinking about NAT screening in blood centers. At present, previously known problems with PCR contamination using open systems have almost become unknown in practice. Standardization of NAT enables comparison and rating of NAT assays regarding specificity, sensitivity, and robustness [2]. Today, the focus is set on quality assurance, maximal automation, and consolidation regarding personal and material resources.

In the present issue of Transfusion Medicine and HemoTHERAPY, two blood screening platforms are presented that fulfil the requirements of modern NAT screening. Heim [3] reports the results of the evaluation of the Procleix Ultrio Elite Assay and the Panther system (Grifols) for individual NAT screening of blood, hematopoietic stem cell, tissue and organ donors. Furthermore, other highly automated NAT testing systems, like the autoX 2.0 (GFE Blut), are used for high-throughput blood donation testing. The launching of the new all-in-one NAT testing platform, called Poet, is imminent. In 2015, the new challenge for the German blood centers was the decision made by the Paul Ehrlich Institute (PEI) that all blood components must be tested by HIV-1 NAT systems that are able to exclude or compensate for the potential underestimation or non-recognition of the respective target region [4]. A potential approach could be an NAT test with two different target regions (dual-target NAT). De Zolt et al. [5] present an assay design of a HIV-1 triple-target NAT and routine testing of more than 3.5 million German blood donations.

The appearance of HIV-1 variants shows once again that not even all problems of blood safety have been solved. Apart from the 'old friends' HIV-1, HCV, and HBV, the emerging pathogens are especially an ongoing challenge and motivation for the development of new testing strategies and/or assays. The current focus of health authorities, with the World Health Organization (WHO) at the forefront, is on arthropod-borne viruses (arbovirus) like Zika virus, Chikungunya virus, Dengue virus, and last but not least the WNV. Considerable risk of transfusion transmission of arboviruses exists due to short periods of asymptomatic viremia in populations with variable and sometimes extremely high incidence of arboviral infections. Apart from the WNV, few arbovirus transfusion transmissions have been proven, mostly due to difficulties in ruling out vector-borne transmission in recipients with arbovirus disease [6]. Pisani et al. [7] review the current situation of the WNV in Europe, focusing on Italy, an endemic region for this virus.

Besides the emerging viral threats and, of course, the bacterial contamination risks of platelets and other cell components, the protozoan parasites must not be forgotten regarding blood safety. Currently, this is a minor problem for European blood centers, but due to globalization, transport of goods and travel activity of blood donors, this topic also has to be considered, and risk assessment has to be performed. In the case of the malaria pathogen Plasmodium spec., blood donors have to be tested for Plasmodium antibodies after residence in or visits to endemic regions. In Switzerland, the local blood centers are confronted with increasing inter-

\section{KARGER}

Fax +497614520714
(๑) 2016 S. Karger GmbH, Freiburg

$1660-3796 / 16 / 0433-0155 \$ 39.50 / 0$
Prof. Dr. Jens Dreier

Institut für Laboratoriums- und Transfusionsmedizin

Herz- und Diabeteszentrum Nordrhein-Westfalen, Universitätsklinik der Ruhr-Universität Bochum

Georgstraße 11, 32545 Bad Oeynhausen, Germany

jdreier@hdz-nrw.de 
national migration and travel from Latin America to Europe. Central and South America are endemic regions for several tropical diseases, e.g. the Chagas disease, a zoonosis also known as American trypanosomiasis, which is a potentially life-threatening infection caused by the hemoflagellate protozoan Trypanosoma cruzi. In the absence of its vector, blood-sucking triatomine bugs, one of the potential modes of transmission of Chagas disease in non-endemic regions is through blood and blood products [8]. Experience with selective testing of at-risk blood donors for Trypanosoma cruzi and Plasmodium spp. in Switzerland is presented by Niederhauser et al. [9].
Altogether, this issue of Transfusion Medicine AND Hemotherapy provides an insight into new developments in NAT screening of blood donations, focusing on novel targets and full automation of testing, leading to the further improvement of blood safety.

\section{Disclosure Statement}

The authors declare that they have no conflicts of interest relevant to the manuscript submitted.

\section{References}

Roth WK, Busch MP, Schuller A, Ismay S, Cheng A, Seed CR, Jungbauer C, Minsk PM, Sondag-Thull D Wendel S, Levi JE, Fearon M, Delage G, Xie Y, Jukic I, Turek P, Ullum H, Tefanova V, Tilk M, Reimal R, Castren J, Naukkarinen M, Assal A, Jork C, Hourfar MK, Michel P, Offergeld R, Pichl L, Schmidt M, Schottsted V, Seifried E, Wagner F, Weber-Schehl M, Politis C, Lin CK, Tsoi WC, O’Riordan J, Gottreich A, Shinar E, Yahalom V, Velati C, Satake M, Sanad N, Sisene I, Bon AH, Koppelmann M, Flanagan P, Flesland O, Brojer E, Lętowska M, Nascimento F, Zhiburt E, Chua SS, Teo D, Stezinar SL, Vermeulen M, Reddy R, Park Q, Castro E, Eiras A, Gonzales Fraile I, Torres P, Ekermo B, Niederhauser C, Chen H, Oota S, Brant LJ, Eglin R, Jarvis L, Mohabir L, Brodsky J, Foster G, Jennings C, Notari E, Stramer S, Kessler D, Hillyer C, Kamel H, Katz L, Taylor C, Panzer S, Reesink HW: International survey on NAT testing of blood donations: expanding implementation and yield from 1999 to 2009. Vox Sang 2012;102:82-90.
Baylis SA, Chudy M, Nübling CM. Standardization of NAT for blood-borne pathogens. Transfus Med Hemother 2015;42:211-218.

3 Heim A: Evaluation of the Procleix Ultrio Elite assay and the Panther system for individual NAT screening of blood, hematopoetic stem cell, tissue and organ donors. Transfus Med Hemother 2016;43: DOI: 10.1159/000446217.

4 Paul-Ehrlich-Institut: Bekanntmachung über die Zulassung von Arzneimitteln - Abwehr von Arzneimittelrisiken - vom 15. Juni 2012: Anordnung von Auflagen zu den Zulassungen für zelluläre Blutkomponenten und gefrorene Frischplasmen, hier Anordnung von Maßnahmen zur Risikominimierung beim Einsatz von HIV-1 NAT-Testsystemen. BAnz AT 2012;2.09.2012 B6.

5 De Zolt S, Thermann R, Bangsow T, Pichl L, Müller B, Jork C, Weber-Schehl M, Hedges D, Schupp I, Unverzagt P, de Rue K, Roth WK: Implementation of a HIV-1 triple target NAT assay in the routine screening at three German Red Cross Blood Centres. Transfus Med Hemother 2016;43: DOI: 10.1159/000446290.
Petersen LR, Busch MP: Transfusion-transmitted arboviruses. Vox Sang 2010;98:495-503.

7 Pisani G, Cristiano K, Pupella S, Liumbruno GM: West Nile virus in Europe and safety of blood transfusion. Transfus Med Hemother 2016; 43: DOI: 10.1159/000446219.

8 Angheben A, Boix L, Buonfrate D, Gobbi F, Bisoffi Z, Pupella S, Gandini G, Aprili G: Chagas disease and transfusion medicine: a perspective from non-endemic countries. Blood Transfus 2015;13:540-550.

$\checkmark$ Niederhauser C, Gottschalk J, Tinguely C: Selective testing of at-risk blood donors for Trypanosoma cruzi and Plasmodium spp. in Switzerland. Transfus Med Hemother 2016;43: DOI: 10.1159/000446218. 